\title{
Article \\ Hydroxy Pentacyclic Triterpene Acid, Kaempferol, Inhibits the Human 5-Hydroxytryptamine Type 3A Receptor Activity
}

\author{
Shinhui Lee ${ }^{1,+}\left(\mathbb{D}\right.$, Hee-Soo Seol ${ }^{2,+}$, Sanung Eom ${ }^{1,+}{ }^{\dagger}$, Jaeeun Lee ${ }^{1}{ }^{(0)}$, Chaelin Kim ${ }^{1}$, Jong-Hwan Park ${ }^{2}$, \\ Tae-Hwan Kim ${ }^{3}\left(\mathbb{D}\right.$ and Junho H. Lee ${ }^{1, * \mathbb{D}}$ \\ 1 Department of Biotechnology, Chonnam National University, Gwangju 61186, Korea; \\ dltlstn39@gmail.com (S.L.); yeomself2355@gmail.com (S.E.); je_lee@hugel.co.kr (J.L.); \\ cl215@biometro.net (C.K.) \\ 2 College of Veterinary Medicine and Animal Medical Institute, Chonnam National University, \\ Gwangju 61886, Korea; heesoo@hugel.co.kr (H.-S.S.); jonpark@jnu.ac.kr (J.-H.P.) \\ 3 Department of Animal Science, Chonnam National University, Gwangju 61886, Korea; grassl@chonnam.ac.kr \\ * Correspondence: leejunho@chonnam.ac.kr; Tel.: +82-62-530-2164 \\ + These authors contributed equally to this work.
}

check for updates

Citation: Lee, S.; Seol, H.-S.; Eom, S.; Lee, J.; Kim, C.; Park, J.-H.; Kim, T.-H.; Lee, J.H. Hydroxy Pentacyclic Triterpene Acid, Kaempferol, Inhibits the Human 5-Hydroxytryptamine Type 3A Receptor Activity. Int. J. Mol Sci. 2022, 23, 544. https://doi.org/ 10.3390/ijms23010544

Academic Editor: Sunoh Kim

Received: 16 December 2021

Accepted: 3 January 2022

Published: 4 January 2022

Publisher's Note: MDPI stays neutral with regard to jurisdictional claims in published maps and institutional affiliations.

Copyright: (C) 2022 by the authors. Licensee MDPI, Basel, Switzerland. This article is an open access article distributed under the terms and conditions of the Creative Commons Attribution (CC BY) license (https:// creativecommons.org/licenses/by/ $4.0 /)$

\begin{abstract}
Monoamine serotonin is a major neurotransmitter that acts on a wide range of central nervous system and peripheral nervous system functions and is known to have a role in various processes. Recently, it has been found that 5-HT is involved in cognitive and memory functions through interaction with cholinergic pathways. The natural flavonoid kaempferol (KAE) extracted from Cudrania tricuspidata is a secondary metabolite of the plant. Recently studies have confirmed that KAE possesses a neuroprotective effect because of its strong antioxidant activity. It has been confirmed that KAE is involved in the serotonergic pathway through an in vivo test. However, these results need to be confirmed at the molecular level, because the exact mechanism that is involved in such effects of KAE has not yet been elucidated. Therefore, the objective of this study is to confirm the interaction of $\mathrm{KAE}$ with $5-\mathrm{HT}_{3 \mathrm{~A}}$ through electrophysiological studies at the molecular level using KAE extracted from Cudrania tricuspidata. This study confirmed the interaction between 5- $\mathrm{HT}_{3 \mathrm{~A}}$ and KAE at the molecular level. KAE inhibited $5-\mathrm{HT}_{3 \mathrm{~A}}$ receptors in a concentration-dependent and voltage-independent manner. Site-directed mutagenesis and molecular-docking studies confirmed that the binding sites D177 and F199 are the major binding sites of human 5-HT 3 A receptors of KAE.
\end{abstract}

Keywords: serotonin receptor; Kaempferol; hydroxy pentacyclic; neuroprotective; TEVC

\section{Introduction}

Monoamine serotonin (5-HT, 5-hydroxytryptamine) is a major neurotransmitter that acts on a wide range of central nervous system (CNS) and peripheral nervous system (PNS) functions. It is known to have a role in various processes such as immunity, gastrointestinal physiology [1], activity rhythms, sexual behavior, and emotional state [2]. Recently, it has been found that 5-HT is involved in cognitive and memory functions through interaction with cholinergic pathways [3]. Receptors that are activated by serotonin are divided into 5-HT1-5-HT7 classes [4] with various subtypes [1]. While other 5-HT receptors (5-HTRs) are G-protein coupled receptors (GPCRs) that serve as second messengers [5], 5-HT3 receptors are ligand-gated cation channels activated by binding of ligand for rapid synaptic neurotransmission [6].

$5-\mathrm{HT}_{3 \mathrm{~A}}$ is a representative receptor of $5-\mathrm{HT}_{3} \mathrm{Rs}$ comprising five A subunits to form a homomeric pentamer with subunits surrounding the central ion-permeable pore [7]. The ligand-binding site of 5- $\mathrm{HT}_{3 \mathrm{~A}}$ is a 'conserved aromatic cage' formed by W63, Y126, W156, Y207, and F199 at the A+A interaction surface of the extracellular domain (ECD) [8]. Ligand binding causes a conformational change [8] and opens the central ion pore that allows cations to pass through the central pore [9]. It is known that $5-\mathrm{HT}_{3 \mathrm{~A}}$ expressed in 
pre-synaptic neurons can induce calcium influx, which plays a critical role in the release of neurotransmitters. When they are expressed in post-synaptic neurons, they can induce $\mathrm{K}^{+}$and $\mathrm{Na}^{+}$-mediated rapid depolarization [10]. This process can convert chemical signals into electrical signals [11].

Cudrania tricuspidata (silkworm thorn), a regional plant containing several flavonoids and xanthones, has been used in traditional medicine. It possesses anti-cancer effects against various tumors [12,13]. The natural flavonoid kaempferol (KAE), extracted from Cudrania tricuspidata, is a secondary metabolite of the plant. It is well known for its anticancer and anti-inflammatory activities [14]. KAE has a yellow color with a diphenyl propane structure (C6-C3-C6) [15]. Recently studies have confirmed that KAE possesses a neuroprotective effect [16] because of its strong antioxidant activity [17]. KAE can inhibit xanthine oxidase that generates reactive oxygen species (ROS) [18] and increase activities of antioxidant enzymes (superoxide mutase, catalase, and heme oxygenase-1). It can also inhibit lipid peroxidation induced by ROS [19]. It is known that excessive accumulation of metal ions such as $\mathrm{Fe}^{3+}$ and $\mathrm{Al}^{3+}$ can induce neurodegenerative diseases [20]. However, KAE has the ability to remove ferrous and cuprous ions as a chelator.

It has been confirmed that KAE is involved in the serotonergic pathway through an in vivo test [21]. However, these results need to be confirmed at the molecular level because the exact mechanism involved in such effects of KAE has not yet been elucidated. Therefore, the objective of this study is to confirm the interaction of KAE with 5- $\mathrm{HT}_{3 \mathrm{~A}}$ through electrophysiological studies at the molecular level using KAE extracted from Cudrania tricuspidata. This study confirmed the interaction between 5- $\mathrm{HT}_{3 \mathrm{~A}}$ and $\mathrm{KAE}$ at the molecular level. KAE inhibited $5-\mathrm{HT}_{3 \mathrm{~A}}$ receptors in a concentration-dependent and voltage-independent manner.

\section{Results}

\subsection{Kaempferol Inhibits Human 5-HT $3 A$ Receptor in a Reversible and} Concentration-Dependent Manner

As shown in Figure 1A, the presence of four hydroxyl groups (-OH) $\left(3,5,7,4^{\prime}\right)$ in the structure of $\mathrm{KAE}$ is the reason why it exhibits a strong antioxidant effect. To confirm the activity of kaempferol (KAE) for $5-\mathrm{HT}_{3 \mathrm{~A}}$ receptors, serotonin and $\mathrm{KAE}$ were applied to oocytes expressing human $5-\mathrm{HT}_{3 \mathrm{~A}}$. Receptor expression was confirmed by applying a control ligand serotonin. The induced-inward current $\left(\mathrm{I}_{5-\mathrm{HT}}\right)$ was measured after treatment with serotonin or KAE through the two-electrode voltage clamp (TEVC). In Figure 1B, serotonin and KAE $100 \mu \mathrm{M}$ were applied to confirm the activation manner on 5- $\mathrm{HT}_{3 \mathrm{~A}}$. It was confirmed that KAE had a reversible inhibitory manner to $5-\mathrm{HT}_{3 \mathrm{~A}}$ receptors. The inhibition percentage by $\mathrm{KAE}$ at $100 \mu \mathrm{M}$ was $74.6 \pm 9.5 \%$. Figure $1 \mathrm{C}$ confirms the inhibitory effect of $\mathrm{KAE}$ on $5-\mathrm{HT}_{3 \mathrm{~A}}$. Different concentrations $(3 \mu \mathrm{M}$ to $300 \mu \mathrm{M})$ of KAE and a fixed concentration of serotonin were used and confirmed that when increasing KAE concentration, the inhibition percentage also increased. KAE inhibited 5- $\mathrm{HT}_{3 \mathrm{~A}}$ in a concentration-dependent manner. Figure 1D, using the Hill equation, expressed concentration-dependent manner as a normalized curve fitting, the $\mathrm{IC}_{50}$ value was $12.8 \pm 2.0 \mu \mathrm{M}$ and Hill coefficient value was $0.9 \pm 0.1$. It confirmed that the $\mathrm{KAE}$ has the concentration-dependent and reversible manner on human $5-\mathrm{HT}_{3 \mathrm{~A}}$ receptors.

\subsection{Kaempferol Inhibits Human 5-HT ${ }_{3 A}$ Receptor in a Voltage-Independent and Non-Competitive Manner}

To confirm whether the inhibition manner of the $5-\mathrm{HT}_{3 \mathrm{~A}}$ receptor by $\mathrm{KAE}$ was affected by voltage, the clamp voltage was artificially changed from -80 to $+60 \mathrm{mV}$. Results are shown in Figure 2A. Water-injected oocytes (red line) were not affected by KAE. After applying $100 \mu \mathrm{M}$ of serotonin to $5-\mathrm{HT}_{3 \mathrm{~A}} \mathrm{mRNA}$ injected oocytes (purple line), the constant slope was not affected by voltage fluctuation and the reversal potential was close to $0 \mathrm{mV}$. There was only a difference in induced-inward current between treatments with $10 \mu \mathrm{M}$ (green line) and $100 \mu \mathrm{M}$ (orange line) of KAE. Results confirmed that KAE inhibition was not affected by voltage fluctuations. Thus, it had an inhibitory effect in a voltage- 
independent manner. To determine whether KAE had a competitive manner to inhibit the $5-\mathrm{HT}_{3 \mathrm{~A}}$ receptor, KAE concentration was fixed while serotonin concentration was changed. After fixing the concentration of $\mathrm{KAE}$ to be $0 \mu \mathrm{M}(\boldsymbol{\square}), 10 \mu \mathrm{M}(\bullet)$, or $100 \mu \mathrm{M}(\boldsymbol{\Delta})$, serotonin concentration was changed from $1 \mu \mathrm{M}$ to $300 \mu \mathrm{M}$. Results are presented as sigmoid curve expectation through the Hill equation. As shown in Figure 2B, efficacy change was confirmed rather than potency. KAE showed an inhibitory effect in a non-competitive manner. When applied KAE concentrations were $0 \mu \mathrm{M}, 10 \mu \mathrm{M}$, and $100 \mu \mathrm{M}$, effectiveness indicator $\mathrm{E}_{\max }$ values were $100.4 \pm 2.1 \%, 79.3 \pm 4.8 \%$, and $37.7 \pm 1.2 \%$, respectively.

\section{A}<smiles>O=c1c(O)c(-c2ccc(O)cc2)oc2cc(O)cc(O)c12</smiles>

B

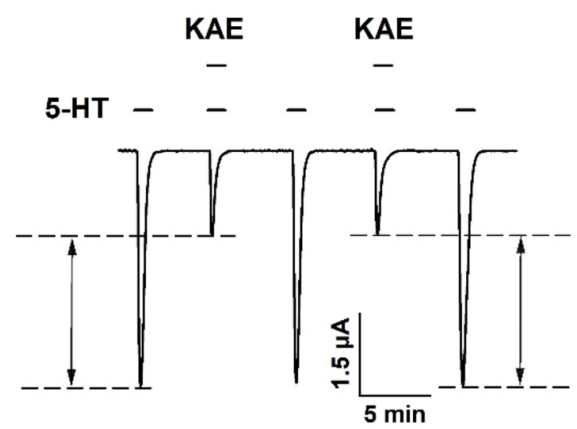

D

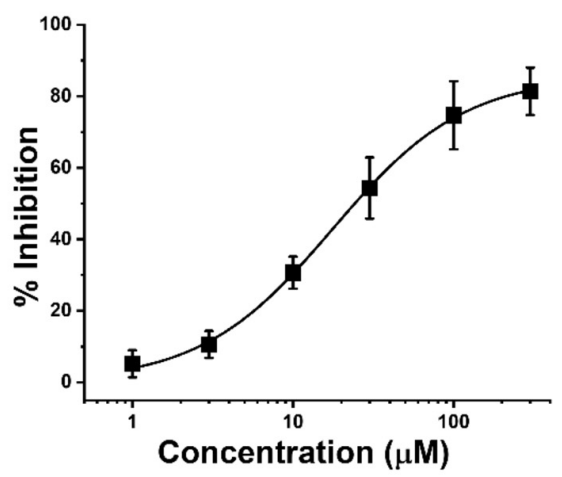

Figure 1. Chemical structure of Kaempferol (KAE) and activation manner confirmed by application to Xenopus oocytes expressing human 5- $\mathrm{HT}_{3 \mathrm{~A}}$ receptor. (A) Structure of KAE. (B-D) Confirmation of KAE's inhibition on $I_{5-H T}$ using a two-electrode voltage clamp. (B) Confirmation of the inhibitory manner of KAE on $I_{5-\mathrm{HT}}$. Black bars indicate applied serotonin and KAE. Applied concentration of serotonin and KAE was $100 \mu \mathrm{M}$. The black dot line indicated in the figure represents the inward current changed when KAE was applied with the control ligand (5-HT, $100 \mu \mathrm{M})(n=6-8$ oocytes from four different frogs). (C) Confirmation of concentration-dependent inhibitory manner of KAE on $I_{5-\mathrm{HT}}$. Black bar indicates the application serotonin and KAE. The applied concentration of serotonin was fixed at $100 \mu \mathrm{M}$ and the applied concentration of KAE is indicated in the figure $(3-300 \mu \mathrm{M})(n=7-9$ oocytes from four different frogs). (D) $I_{5-\mathrm{HT}}$ inhibitory current according to the concentration-specific application of KAE is shown as a normalized curve. The inhibition percentage for human $5-\mathrm{HT}_{3 \mathrm{~A}}$ was fitted to the Hill equation. The $x$-axis shows the applied concentration of KAE and the $y$-axis shows the inhibition percentage of $\mathrm{KAE}$ on $5-\mathrm{HT}_{3 \mathrm{~A}}$. Each point represents the inhibition percentage, error value, and mean \pm SEM ( $n=7-9$ oocytes from four different frogs) according to statistical analysis. All experiments were carried out at $-80 \mathrm{mV}$ voltage-clamp holding potential and the rate of application of the agent was $2 \mathrm{~mL}$ per min. 
A

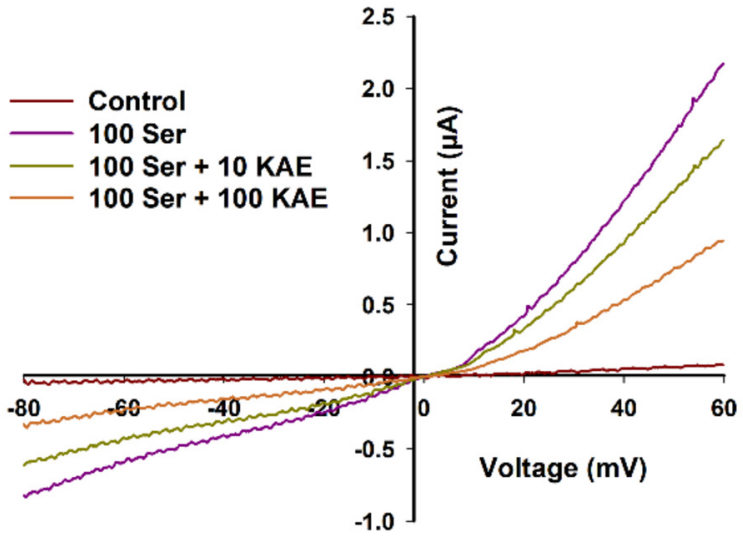

B

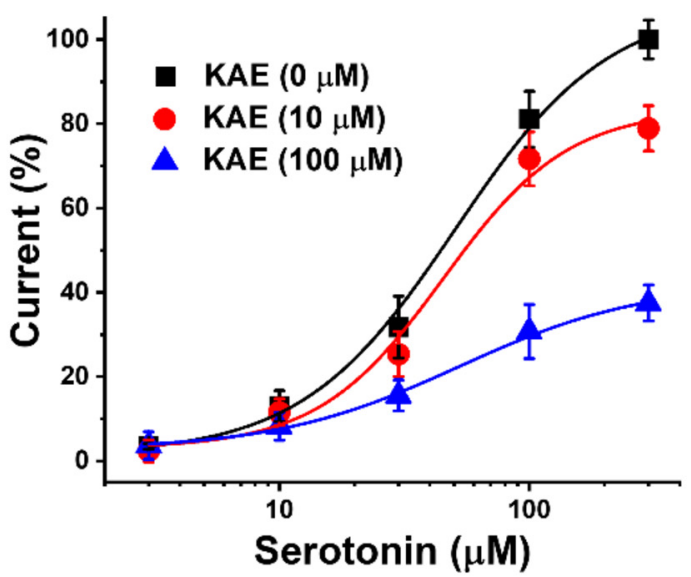

Figure 2. (A) Effects of voltage on the relationship of KAE with human 5- $\mathrm{HT}_{3 \mathrm{~A}}$ receptor. Different voltages ranging from $-80 \mathrm{mV}$ to $+60 \mathrm{mV}$ were applied to oocytes injected with water (control) or $5-\mathrm{HT}_{3 \mathrm{~A}}$ mRNA using the voltage clamp ramp protocol. The holding potential of the membrane was fixed at $-80 \mathrm{mV}$. The color of each line indicates the applied condition (red = water injection, purple $=100 \mu \mathrm{M}$ serotonin applied, green $=100 \mu \mathrm{M}$ serotonin and $10 \mu \mathrm{M}$ KAE applied, orange $=100 \mu \mathrm{M}$ serotonin and $100 \mu \mathrm{M} \mathrm{KAE}$ applied; $n=8-10$ oocytes from four different frogs). (B) Confirmation of a non-competitive interaction between KAE and human 5-HT3A. In oocytes injected with human $5-\mathrm{HT}_{3 \mathrm{~A}}$ mRNA, the concentration of $\mathrm{KAE}$ was fixed at $0 \mu \mathrm{M}(\boldsymbol{\square}), 10 \mu \mathrm{M}(\bullet)$, or $100 \mu \mathrm{M}(\mathbf{\Delta})$ while the concentration of serotonin ranged from 1 to $300 \mu \mathrm{M}$. Membrane holding potential was fixed at $-80 \mathrm{mV}$. Each point represents the current percentage and error value due to change in the concentration of serotonin. Data are presented as mean \pm SEM ( $n=7-9$ oocytes from four different frogs) according to statistical analysis.

\subsection{Docking Modeling of Human 5-HT $\mathrm{T}_{3 A}$ Receptor Interacting with Kaempferol}

Figure 3 shows the KAE binding site on the human $5-\mathrm{HT}_{3 \mathrm{~A}}$ receptor through the protein modeling. It is known that $5-\mathrm{HT}_{3 \mathrm{~A}}$ has a homo pentamer structure composed of five A subunits and three domains: an extracellular domain (ECD), which is the main binding site for ligand and competitive antagonist, a transmembrane domain (TMD), which is the main binding site for non-competitive antagonists with ions conductive structure, and an intracellular domain (ICD) [22]. Each subunit of TMD is composed of four $\alpha$ helices (M1-M4). The M2 domain faces the ion pore [23]. In Figure 4, to confirm the interaction site of KAE on the human $5-\mathrm{HT}_{3 \mathrm{~A}}$ receptor, the in-silico protein-ligand complex modeling was conducted to determine their interaction residues. Figure $4 \mathrm{~A}$ shows the KAE binding interaction in the protein surface model and Figure $4 \mathrm{~B}$ shows the positions of residues that are likely to affect KAE binding. To consider the binding pocket in the most stable energy state, the interaction with KAE was implemented as a 3D model based on the crystal structure information of 5- $\mathrm{HT}_{3 \mathrm{~A}}$ (PDB ID: 6Y1Z). Interaction distances of KAE with each residue of wild-type and mutant-type $5-\mathrm{HT}_{3 \mathrm{~A}}$ receptors are shown in Figure $4 \mathrm{C}, \mathrm{D}$. The binding site of KAE is located at the $\mathrm{A}+\mathrm{A}$ interaction site adjacent to the two A subunits of ECD. This position shared W63, R65, N101, F199, and E209 residues of the conserved aromatic cage of the serotonin binding site [8]. The two adjacent A subunits and chains are shown in different colors. The distance between atoms is also shown in the Figure 4. 

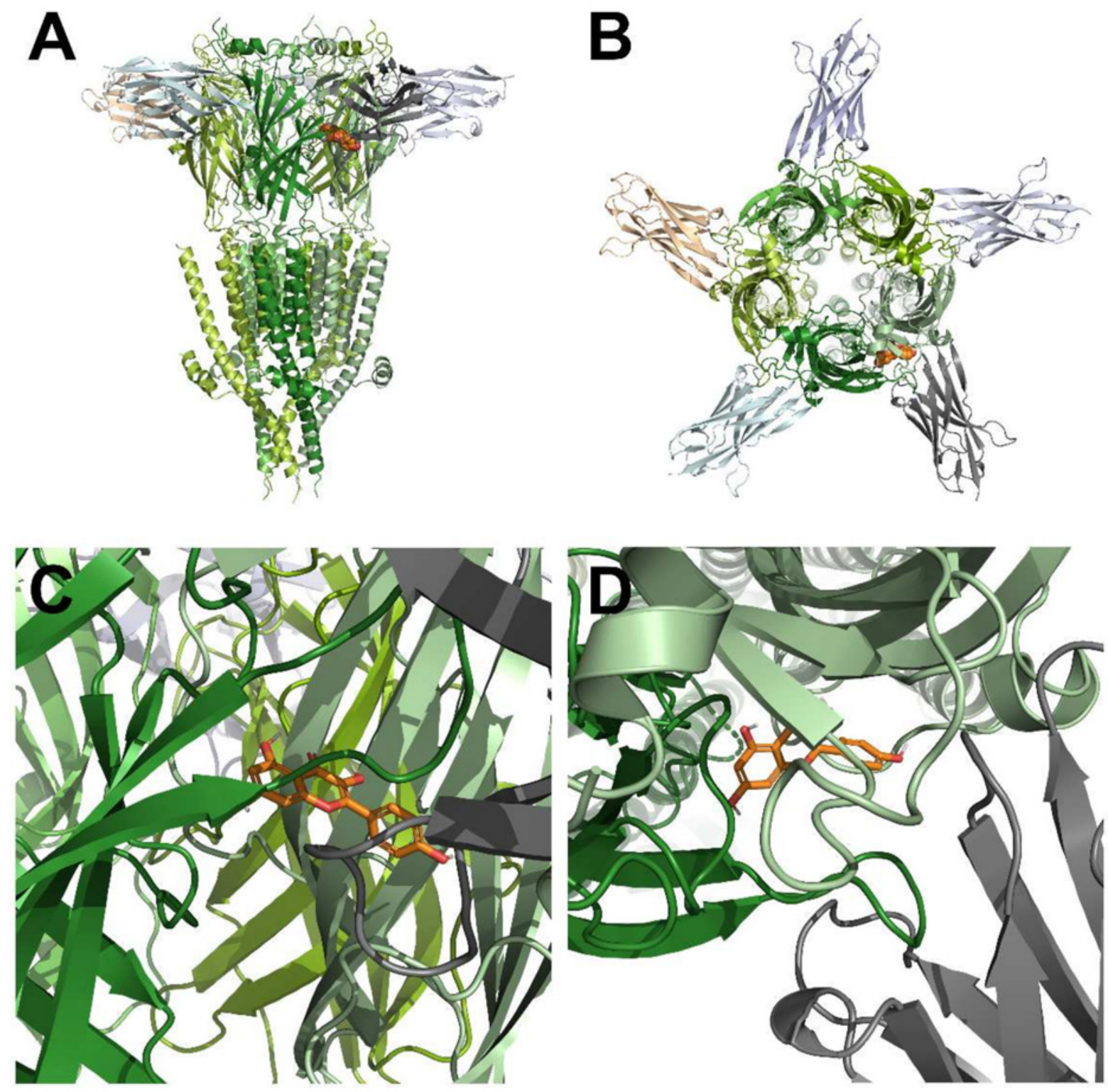

Figure 3. 3D docking modeling of $\mathrm{KAE}$ on human $5-\mathrm{HT}_{3 \mathrm{~A}}$ receptor. (A-C) Docked complex of $5-\mathrm{HT}_{3 \mathrm{~A}}$ receptor and KAE from the side. (B-D) Docked complex of 5- $\mathrm{HT}_{3 \mathrm{~A}}$ receptor and KAE from the top.

\subsection{Inhibitory Effect of Kaempferol on a Double-Mutant Type Human 5-HT $3 A$ Receptor}

Among KAE's eight interaction sites (Figure 3B) identified in the human 5- $\mathrm{HT}_{3 \mathrm{~A}}$ receptor, a point mutation was performed to determine which residues could critically affect their binding. Each candidate residue was substituted with alanine in the mutagenesis experiment. After mRNA was injected into oocytes and expressed, the activity of the 5$\mathrm{HT}_{3 \mathrm{~A}}$ receptor was measured with TEVC. It was expected that residues that did not affect the binding of KAE would not significantly affect the binding if they were substituted with alanine. The most influential interaction residues were identified by confirming the inhibition of wild-type and mutant-type 5- $\mathrm{HT}_{3 \mathrm{~A}}$ by KAE. Results are shown in Figure 5A,B. To confirm that the residue significantly affected the KAE's inhibition ability, each mutant type, and the inhibition percentage of $\mathrm{KAE}$, were presented as a sigmoid curve using Hill equation. Results are shown in Figure 5D. The half-inhibitory concentration $\left(\mathrm{IC}_{50}\right)$ of $\mathrm{KAE}$ was $23.4 \pm 23.9 \mu \mathrm{M}$ for wild-type $5-\mathrm{HT}_{3 \mathrm{~A}}, 41.4 \pm 7.4 \mu \mathrm{M}$ for D177 residue mutant, and $57.2 \pm 20.8 \mu \mathrm{M}$ for F199 residue mutant. Maximum-inhibitory percentage $\left(\mathrm{I}_{\max }\right)$ by KEA was $79.3 \pm 4.5 \%$ for wild-type $5-\mathrm{HT}_{3 \mathrm{~A}}, 47.2 \pm 1.3 \%$ for D177 residue mutant, and 
$25.8 \pm 1.42 \%$ for F199 residue mutant. In the case of D177 and F199 double-mutant, the $\mathrm{IC}_{50}$ value was $26.0 \pm 9.5 \mu \mathrm{M}$ and the $\mathrm{I}_{\max }$ was $11.9 \pm 1.2 \%$. The substitution of D177 and F199 residues of 5- $\mathrm{HT}_{3 \mathrm{~A}}$ receptor with alanine significantly offset the inhibition by KAE (Figure 5). These results confirmed that the crucial binding sites of human $5-\mathrm{HT}_{3 \mathrm{~A}}$ for KAE were D177 and F199. Table 1 shows KAE inhibition according to 5-HT 3 A mutanttype obtained by point mutation, after selecting the most promising candidate residues by predicting the interaction between wild-type or mutant-type 5- $\mathrm{HT}_{3 \mathrm{~A}}$, and $\mathrm{KAE}$ and $\mathrm{I}_{\max }$ (maximum-inhibitory percentage), $\mathrm{IC}_{50}$ (half-inhibitory concentration), and $\mathrm{n}_{\mathrm{H}}$ (Hill coefficient) values are shown.
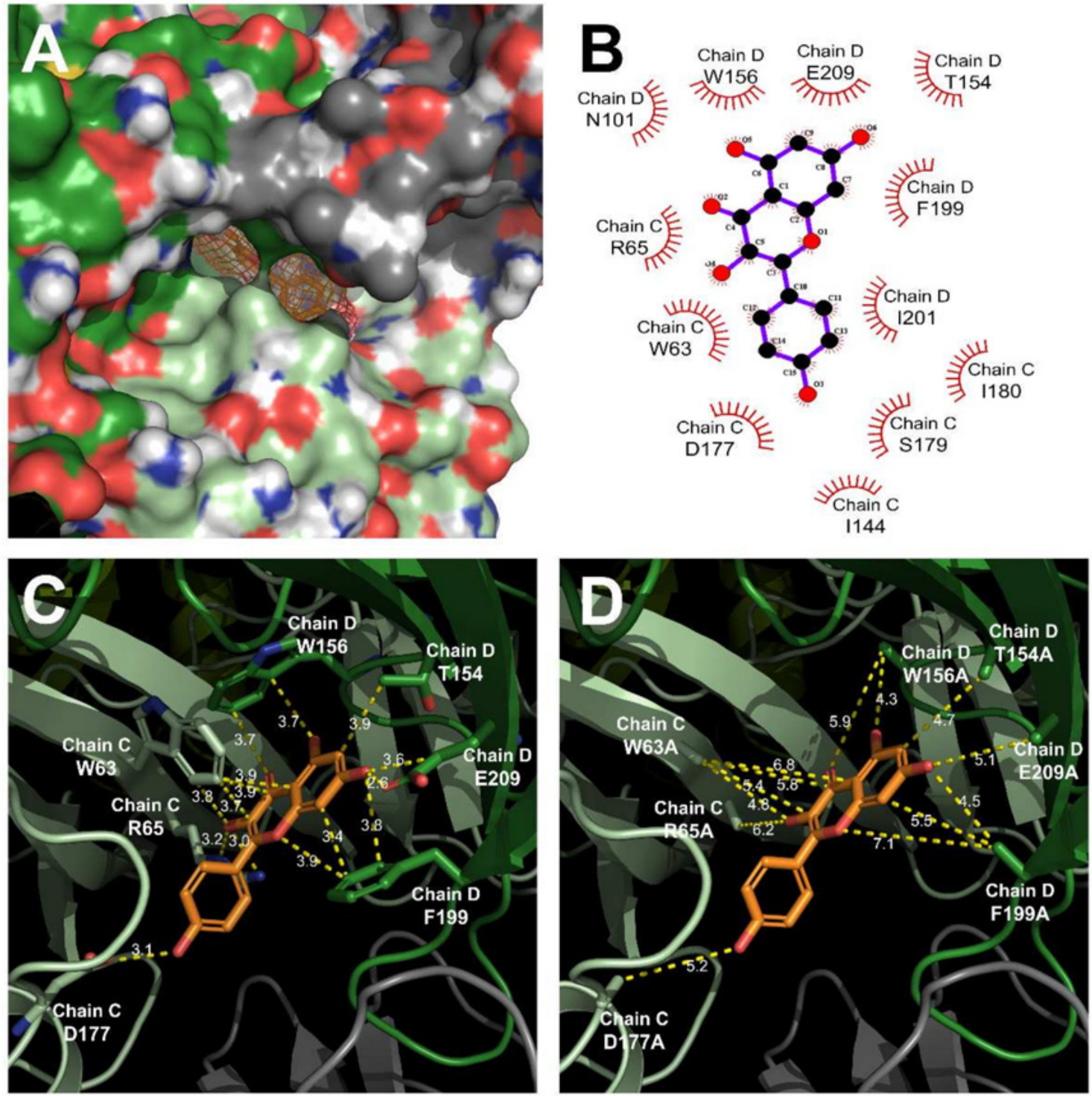

Figure 4. KAE binding pocket and docking modeling of human 5- $\mathrm{HT}_{3 \mathrm{~A}}$ receptor by $3 \mathrm{D}$ protein modeling. (A) $5-\mathrm{HT}_{3 \mathrm{~A}}$ protein surface modeling on KAE binding site. KAE is docked between the two A subunits of the extracellular domain (ECD). (B) Interaction residues of KAE in 5-HT $3 \mathrm{~A}$ are predicted by 2D schema. (C) Interaction energy of KAE between the two A subunits of the wild-type human 5- $\mathrm{HT}_{3 \mathrm{~A}}$ receptor. (D) Interaction energy of $\mathrm{KAE}$ between the two A subunits of the mutant-type human 5- $\mathrm{HT}_{3 \mathrm{~A}}$ receptor. Distances between each chain, residue, and atom are shown in the figure. 
A D177A

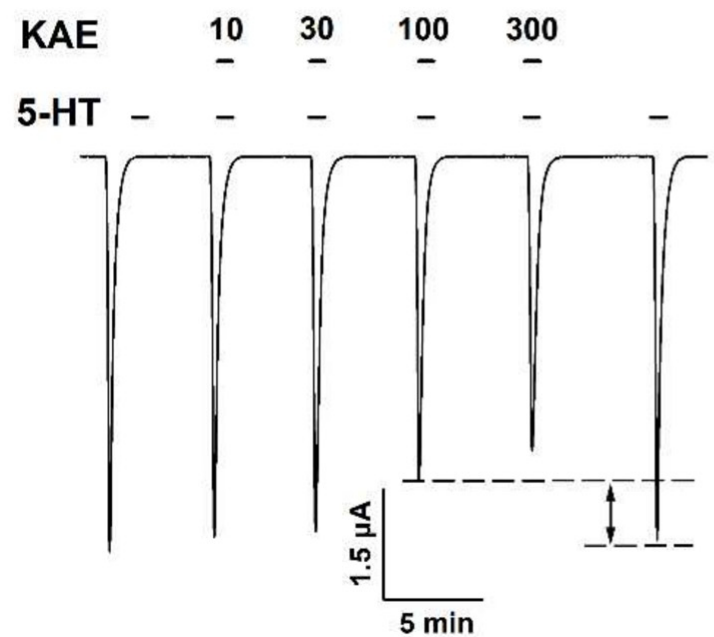

\section{D177A + F199A}

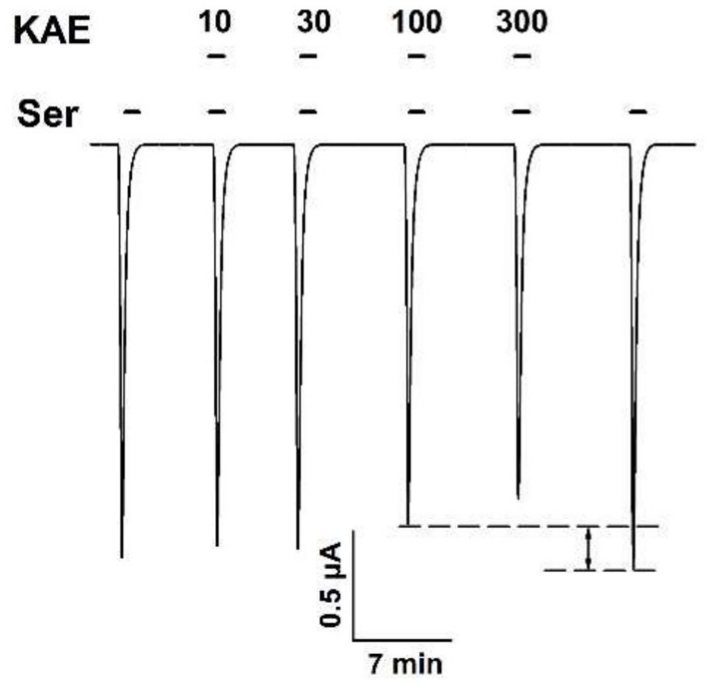

B F199A

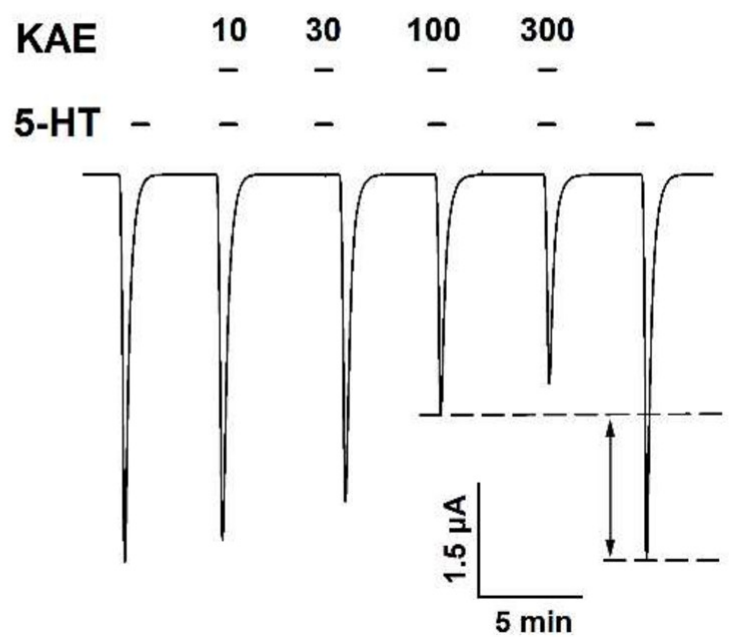

D

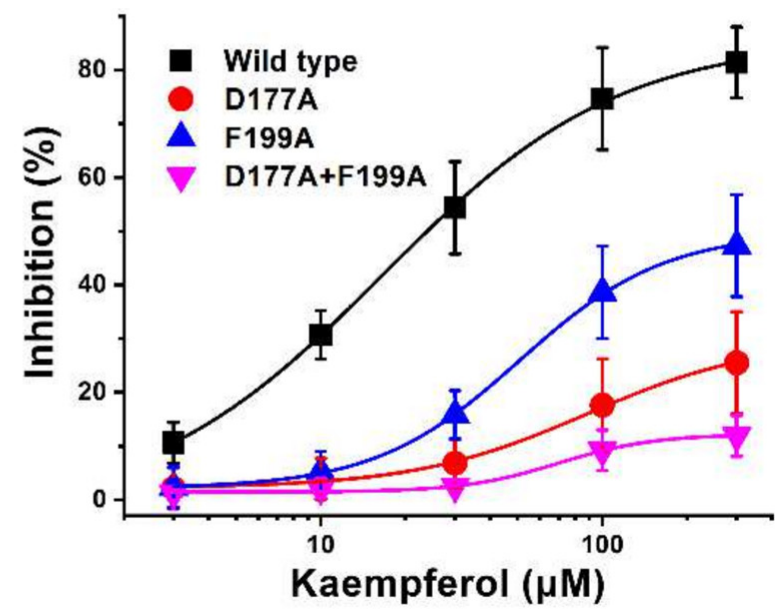

Figure 5. Inhibition of KAE according to mutant-type of 5- $\mathrm{HT}_{3 \mathrm{~A}}$ receptor. (A-C) Inward current when KAE was applied to 5- $\mathrm{HT}_{3 \mathrm{~A}}$ single-mutant types (D177 or F199 residue substitution) and doublemutant type (both D177 and F199 residue substitutions). The applied concentration of serotonin was fixed at $100 \mu \mathrm{M}$, while the concentration of $\mathrm{KAE}$ was $10 \mu \mathrm{M}, 30 \mu \mathrm{M}, 100 \mu \mathrm{M}$, or $300 \mu \mathrm{M}$. Black bar indicates the applied serotonin and KAE. The black dot line indicated in the figure represents the inward current changed when KAE was applied with the control ligand $(5-\mathrm{HT}, 100 \mu \mathrm{M})(n=6-8$ oocytes from four different frogs). (D) Inhibition percentage of wild-type and single or double-mutant type of $5-\mathrm{HT}_{3 \mathrm{~A}}$ receptor by KAE. Each point represents the inhibition percentage and error value for each concentration of KAE. Data are presented as mean \pm SEM $(n=9-11$ oocytes from four different frogs) according to statistical analysis. 
Table 1. Effects of KAE on wild-type and mutant of human $5-\mathrm{HT}_{3 \mathrm{~A}}$ receptor.

\begin{tabular}{cccc}
\hline Mutant Type & $\mathbf{V}_{\max }$ & $\mathbf{I C}_{\mathbf{5 0}}$ & $\boldsymbol{n}$ \\
\hline Wild type & $79.3 \pm 4.6$ & $23.4 \pm 8.3$ & $1.2 \pm 0.3$ \\
R65A & $82.6 \pm 7.4$ & $44.7 \pm 9.1$ & $1.8 \pm 0.7$ \\
W63A & $76.3 \pm 10.7$ & $33.7 \pm 5.7$ & $1.3 \pm 0.5$ \\
N101A & $83.7 \pm 8.6$ & $56.4 \pm 9.7$ & $1.1 \pm 0.6$ \\
I144A & $71.6 \pm 11.8$ & $34.9 \pm 11.2$ & $1.5 \pm 0.4$ \\
T154A & $73.5 \pm 9.4$ & $33.4 \pm 7.9$ & $1.1 \pm 0.4$ \\
D177A & $23.3 \pm 13.4$ & $13.9 \pm 4.2$ & $1.3 \pm 0.2$ \\
I180A & $89.5 \pm 12.1$ & $45.5 \pm 12.9$ & $1.8 \pm 0.6$ \\
F199A & $53.3 \pm 10.4$ & $21.5 \pm 5.7$ & $1.7 \pm 0.4$ \\
E209A & $81.1 \pm 9.7$ & $55.1 \pm 5.8$ & $1.8 \pm 0.5$ \\
I210A & $78.4 \pm 11.4$ & $35.4 \pm 9.7$ & $1.3 \pm 0.4$ \\
D177A+F199A & $11.9 \pm 1.2$ & $42.9 \pm 10.2$ & \\
\hline
\end{tabular}

The values represent the mean \pm S.E.M $(n=9-11$ oocytes from four different frogs). Currents were elicited at a holding potential of $-80 \mathrm{mV}$. $\mathrm{IC}_{50}(\mu \mathrm{M})$, Hill coefficient $(\mathrm{n})$, and $\mathrm{V}_{\max }(\%)$ were determined as described in Materials and Methods.

\section{Discussion}

Kaempferol (KAE) has a strong antioxidant effect due to the presence of a C2-C3 double bond, a C4 oxo group, and four hydroxy groups $(-\mathrm{OH})\left(3,5,7,4^{\prime}\right)$ in its structure [15]. Reactive oxygen species (ROS) scavenging is a very important function. Excess ROS can induce oxidative stress and provoke cellular redox change, leading to mitochondrial dysfunction, and because of this, the apoptosis-related factors are released into the cytosol, which can lead to programmed cell death [24]. Brain cells' excessive ROS can react with macromolecular cells through oxidation, leading to cell death or necrosis [25]. Through an in vivo test, it has been confirmed that mice fed with KAE show improvement of arrangement, distribution, and morphological structure of neuronal cells in their brains [26]. In addition, it has been confirmed that KAE can decrease oxidative stress by regulating the expression of apoptosis-related protein [26]. KAE has antioxidant effects in the CNS. It can prevent apoptosis caused by ROS stress. Thus, KAE seems to have a neuroprotective function.

This study confirmed the interaction between $5-\mathrm{HT}_{3 \mathrm{~A}}$ and $\mathrm{KAE}$ at the molecular level. $\mathrm{KAE}$ inhibited $5-\mathrm{HT}_{3 \mathrm{~A}}$ receptors in a concentration-dependent and a voltage-independent manner. Regarding the inhibitory manner of KAE, when applying serotonin, in the case of a competitive antagonist, a changed potency (effective dose), but a non-competitive antagonist has different efficacy (maximum effect) $[27,28]$. The present study confirmed that KAE possessed an inhibitory effect in a non-competitive manner that affected the efficacy, but not the potency (Figure 2B). The binding site of serotonin is in the A+A subunit interaction site. Other subtypes also have this interaction site, which is the reason why serotonin acts as a ligand in $5-\mathrm{HT}_{3 \mathrm{AB}}$ and other $5-\mathrm{HT}_{3} \mathrm{R}$ subtypes. Therefore, it is highly possible that a competitive $5-\mathrm{HT}_{3} \mathrm{R}$ antagonist can act on other $5-\mathrm{HT}_{3} \mathrm{R}$ subtypes [23]. In the case of a non-competitive antagonist, it is highly possible that it does not affect other subtypes. Although it is unaffected by the presence of serotonin, it can be a more effective drug against a target receptor than a competitive antagonist [1].

Among the residues that affected the binding of KAE, it was confirmed that D177 and F199 were major binding sites according to changed interaction distances obtained by amino acid residue substitution on the mutant-type $5-\mathrm{HT}_{3 \mathrm{~A}}$ receptor (Figure $5 \mathrm{C}$ ). Among binding sites, F199 shared with serotonin's binding pocket residue. However, it was confirmed that D177 had more contribution to the binding through comparison of Imax values. The binding site of $\mathrm{KAE}$ in $5-\mathrm{HT}_{3 \mathrm{~A}}$ is in the $\mathrm{ECD}$, which has a major ligand and competitive antagonist binding site at the $5-\mathrm{HT}_{3 \mathrm{~A}}$ receptor and differs from TMD in that it has a major non-competitive antagonist binding site [4].

$5-\mathrm{HT}_{3 \mathrm{~A}}$ is mainly expressed in neuronal cells in regions such as the cerebral cortex, hippocampus, amygdala, and olfactory bulb in the CNS. It is also expressed in non-neuronal cells such as $\mathrm{T}$ cells, monocytes, synovial tissue, and primary chondrocytes [29]. Its 
antagonist can be used as a therapeutic agent for physiological, emotional, cognitive, appetite, sleep, sexual, anxiety, learning, and memory dysfunctions [30]. It has been confirmed through in vivo test that excessive activity of $5-\mathrm{HT}_{3} \mathrm{R}$ can induce excitotoxic neuronal death, leading to early neuronal cell death [31].

A previously study has confirmed the interaction between human $5-\mathrm{HT}_{3 \mathrm{~A}}$ and antagonist Schisandrin $C$ and discussed their relationship with irritable bowel syndrome (IBS) and the potential of Schisandrin $C$ as a therapeutic agent [32]. The KAE used in this study has lipophilia properties and ability to penetrate the lipid bilayer. Thus, it can cross the blood-brain barrier (BBB) [15]. Among 5- $\mathrm{HT}_{3 \mathrm{~A}}$ antagonists, those that can cross the BBB are suitable for treating neurological diseases such as memory and cognitive impairment, through their interaction mechanism in the CNS, while agents that cannot pass BBB are suitable for treating IBS, nausea, and vomiting [23]. We confirmed that KAE has a great potential as an antagonist of the $5-\mathrm{HT}_{3 \mathrm{~A}}$ receptor through molecular studies.

$5-\mathrm{HT}_{3} \mathrm{Rs}$ are mostly found in the pre-synaptic region associated with axons and nerve terminals except for the hippocampus [33]. 5- $\mathrm{HT}_{3 \mathrm{~A}}$ at the nerve ending can induce rapid $\mathrm{Ca}^{2+}$ influx and regulate the secretion of other neurotransmitters (dopamine, acetylcholine, glutamate, GABA, and serotonin) [7]. The main expression regions of $5-\mathrm{HT}_{3 \mathrm{~A}}$ are the neocortex, hippocampus, and subpopulation of GABAergic interneurons of amygdala [33]. The amygdala and hippocampus are regions related to memory, spatial exploration, emotion regulation, and anxiety. On this path, cholinergic and serotonergic pathways mediate memory activation. It has been shown that long-term potentiation (LTP) related synaptic plasticity can be inhibited by $5-\mathrm{HT}_{3 \mathrm{~A}}$ agonist but activated by antagonist [22]. This is due to activation of the serotonergic pathway in the GABA-ergic interneuron. Thus, it can be seen that this is related to the release of other neurotransmitters by $5-\mathrm{HT}_{3 \mathrm{~A}}$ in the mechanisms related to memory and cognition [22].

Alzheimer's disease is a representative brain disease. It appears to be due to a decrease in cholinergic signaling molecules associated with aging [2]. Age-related cognitive loss is related to dysfunction of serotonergic and cholinergic pathways. Interaction of these two mechanisms is important for the formation of memory and learning [2]. 5- $\mathrm{HT}_{3} \mathrm{R}$ is also expressed in cholinergic axon terminals of the cerebral cortex. It can regulate the release of acetylcholine $(\mathrm{ACh})$ in a tonic inhibition manner. It has been shown that ondansetron, a representative $5-\mathrm{HT}_{3} \mathrm{R}$ antagonist, can enhance the release of $\mathrm{ACh}$ [34]. Comparing the potency of the most representative 5- $\mathrm{HT}_{3}$ antagonist, ondansetron and $\mathrm{KAE}, \mathrm{IC}_{50}$ values were $4.9 \mathrm{nM}$ and $12.8 \mathrm{uM}$, respectively. Comparing the efficacy of antagonists against $I_{5-\mathrm{HT}(100 \mathrm{uM})}$ of $5-\mathrm{HT}_{3 \mathrm{~A}}, \mathrm{KAE}$ is $79.3 \pm 4.6 \%$, and ondansetron is close to $100 \%$ [35-37]. In addition, KAE showed non-competitive inhibition through the above study and ondansetron is a competitive antagonist [1]. Therefore, it can be used to treat cognitive impairment and memory loss by blocking serotonergic activity [38].

Parkinson's disease is caused by a decrease in dopaminergic neurons [19] and can regulate dopamine release through the serotonergic mechanism. It has been reported that decreased serotonin can induce the release of dopamine [39]. KAE is known as an antioxidant effect. In Parkinson's disease, KAE treatment can increase the amount of dopamine precursor and its metabolites. It can also increase activities of antioxidant related enzymes such as superoxide dismutase (SOD) and glutathione peroxidase (GSHPx) [19]. These results indicate that KAE can have a synergic effect because KAE not only can regulate serotonergic pathways, but also can treat brain-related diseases caused by excessive ROS. The finding that KAE can inhibit 5- $\mathrm{HT}_{3 \mathrm{~A}}$ in the $\mathrm{CNS}$ is significant. KAE is expected to have various neuroprotective effects, such as enhancing synaptic plasticity and preventing neurodegenerative diseases (such as Alzheimer's disease, memory disorder, depression, anxiety, drug abuse, stroke, and seizure), by regulating the release of other signaling molecules through its antioxidant effect.

$5-\mathrm{HT}_{3 \mathrm{~A}}$ is closely related to inflammatory responses. $5-\mathrm{HT}_{3 \mathrm{~A}}$ is expressed in extraneuronal cells, and immune cells (T cells, monocytes, chondrocytes, synovial tissue). The movement of $\mathrm{Na}^{+}$and $\mathrm{K}^{+}$ions through this receptor plays an important role in regulating 
the activation and carrying out the aggregation of immune cells in inflammatory events [29]. Aggregated immune cells release growth factors and cytokines. ROS and nitrogen generated in this process are closely related to cellular apoptosis. Excessive ROS can induce oxidative stress, which can damage DNA, protein, and lipids [15]. Chronic inflammation can cause diseases such as cancer, asthma, neurological disorders, and Alzheimer's disease [15]. Excessive activity of $5-\mathrm{HT}_{3} \mathrm{R}$ can accumulate $\mathrm{Ca}^{2+}$, induce $\mathrm{ROS}$ generation, promote abnormal glutamate release, cause imbalance of mitochondria membrane potential, and lead to cytochrome $\mathrm{c}$ being released into the cytosol, which can induce apoptosis (caspase pathway) $[38,40]$. Therefore, anti-inflammatory properties using $5-\mathrm{HT}_{3 \mathrm{~A}}$ antagonists can prevent neuronal apoptosis caused by excessive immune activation, thus preventing neuronal loss with a neuroprotective effect.

5- $\mathrm{HT}_{3} \mathrm{R}$ has subtypes A-E [41]. Studies on subtypes $3 \mathrm{~A}, 3 \mathrm{~B}$, and $3 \mathrm{AB}$ are actively being carried out. Studies on C, D, and E subtypes are also in progress. Antagonists of $5-\mathrm{HT}_{3} \mathrm{R}$ have been used to treat vomiting and nausea. However, these $5-\mathrm{HT}_{3} \mathrm{R}$ receptors regulate various regions of the CNS in a complex manner and modulate the release of other neurotransmitters. They are also involved in nerve interactions. Thus, effects that can be obtained by controlling these receptors are vast [23]. Since 5- $\mathrm{HT}_{3} \mathrm{R}$ regulates the release of other neurotransmitters at synaptic terminals, this mechanism can be targeted as a good approach for treating diseases complexly mediated by neurotransmitters. In addition, in cholinergic signaling, increasing the release of acetylcholine by inhibiting $5-\mathrm{HT}_{3} \mathrm{R}$ can lead to recovery of cognitive function [2]. Thus, the 5- $\mathrm{HT}_{3 \mathrm{~A}}$ antagonist KAE has the potential to be used as a therapeutic agent for cholinergic neurotransmitter deficit. Results of this study obtained at molecular levels are highly likely to be verified through pre-clinic stage studies.

\section{Materials and Methods}

\subsection{Materials}

All reagent stocks used for two-electrode voltage clamp (TEVC) experiments were purchased from Sigma-Aldrich (St. Louis, MO, USA). Human 5- $\mathrm{HT}_{3 \mathrm{~A}}$ (GenBank accession No.: BC004453) DNA was obtained from OriGene (Rockville, MD, USA). Dimethyl sulfoxide (DMSO) was used to make the agent stocks and the final concentration did not exceed 0.01\%. Kaempferol was purchased from Wuhan ChemFac Biochemical (Hubei, China), and 98\% pure Kaempferol 3,4,7-triacetate was used.

\subsection{In Vitro Transcription: Human 5-HT ${ }_{3 A}$ Receptor}

Human 5- $\mathrm{HT}_{3 \mathrm{~A}}$ receptor cDNA was linearized using restriction enzyme XhoI. In vitro transcription was performed using an mMESSAGE mMACHINE T7 Transcription Kit (Thermo Fisher Scientific, Waltham, MA, USA). The final mRNA product was dissolved in $1 X$ Diethyl Pyrocarbonate (RNase-free water) at a final concentration of $1 \mu \mathrm{g} / \mu \mathrm{L}$ and kept in a deep-freezer at $-80{ }^{\circ} \mathrm{C}$ until used.

\subsection{Xenopus Oocytes Preparation and $m R N A$ Microinjection}

Xenopus oocytes were used in this study as cells for expression of human 5- $\mathrm{HT}_{3 \mathrm{~A}}$ receptor. All female frogs used in this experiment were obtained from the Korean Xenopus Resource Center for Research (KXRCR000001). Xenopus management followed the guideline of Chonnam National University institution guidelines (CNU IACUC-YB-2016-07, July 2016). Xenopus oocytes were extracted during ice incubation state and isolated as single oocytes using collagenase II ( $2 \mathrm{mg} / \mathrm{mL})$ in OR2 buffer $(82.5 \mathrm{mM} \mathrm{NaCl}, 2 \mathrm{mM} \mathrm{KCl}, 1 \mathrm{mM}$ $\mathrm{MgCl}_{2}, 5 \mathrm{mM}$ HEPES, $\mathrm{pH}$ 7.4). Isolated oocytes were incubated with ND96 incubation buffer $(96 \mathrm{mM} \mathrm{NaCl}, 2 \mathrm{mM} \mathrm{KCl}, 1 \mathrm{mM} \mathrm{MgCl} 2,1.8 \mathrm{mM} \mathrm{CaCl} 2,5 \mathrm{mM}$ HEPES, $2.5 \mathrm{mM}$ sodium pyruvate, and $50 \mathrm{mg} / \mathrm{mL}$ gentamycin, $\mathrm{pH} 7.4$ ) at $18{ }^{\circ} \mathrm{C}$ until the experiment was performed. Human $5-\mathrm{HT}_{3 \mathrm{~A}}$ receptor mRNA was injected into oocytes using a nanoinjector (Drummond Scientific, Broomall, PA, USA) with a mineral-filled $10 \mu \mathrm{L}$ microdispenser (VWR, Piscataway, NJ, USA). 


\subsection{Electrophysiology Studies: Two-Electrode Voltage Clamp Data Recording}

To confirm the KAE activity on the human $5-\mathrm{HT}_{3 \mathrm{~A}}$ receptor, a two-electrode voltage clamp (OC-725C; Warner Instruments, Hamden, CT, USA) with a Digitata 1550A was used. For the experiment, induced-inward current was converted to digital data with $\mathrm{pClamp}$ 10 software (Axon Instruments, Union City, CA, USA). All experiments were performed at room temperature using an oocyte clamp equipped with Digidata. The membrane holding potential was $-80 \mathrm{mV}$.

The voltage relationship experiment for confirming the relationship between induceinward current and voltage, the voltage was varied from $-80 \mathrm{mV}$ to $+60 \mathrm{mV}$ using a ramp protocol. Each microelectrode was filled with $3 \mathrm{M} \mathrm{KCl}$ having a resistance of $0.2 \mathrm{M} \Omega$. Serotonin and KAE applied in the experiment were diluted in ND96 bath solution $(96 \mathrm{mM}$ $\mathrm{NaCl}, 2 \mathrm{mM} \mathrm{KCl}, 1 \mathrm{mM} \mathrm{MgCl} 2,1.8 \mathrm{mM} \mathrm{CaCl}_{2}$, and $5 \mathrm{mM}$ HEPES, $\mathrm{pH}$ 7.5) to specified concentration. The rate of application of the reagent was $2 \mathrm{~mL}$ per minute. All recording data were analyzed using Clampfit 9.0 (Molecular Devices, San Jose, CA, USA).

\subsection{Point Mutation-Site-Directed Mutagenesis: Mutant Gene Amplification}

Point mutation was performed using Pfu DNA polymerase (Quikchange II SiteDirected Mutagenesis Kit). Chimeric primer design for PCR was performed under appropriate primer design guidelines. To remove methylated cDNA, Dpn I was used. Transformation of the mutated DNA used pGEM vector. pDNA was purified using a miniprep protocol. The acquired mutated human $5-\mathrm{HT}_{3 \mathrm{~A}}$ pDNA was subjected to plasmid DNA sequencing by Cosmo Gentech Inc (Seoul, Seongdong-gu, Korea) to confirm the target residue mutation.

\subsection{Molecular Docking Studies: Protein-Ligand Interaction}

A molecular docking study was performed using Autodock Tools version 1.5.6 (The Scripps Research Institute, La Jolla, CA, U.S.A.) to confirm the interaction of the human $5-\mathrm{HT}_{3 \mathrm{~A}}$ receptor with serotonin and KAE. The crystal structure was obtained from Protein Data Bank (PDB ID: 6Y1Z, 2.82- $\AA$ resolution) for human 5-HT $\mathrm{H}_{3 \mathrm{~A}}$ receptor modeling. Structures of serotonin and KAE were obtained from PubChem (PubChem IDs: 443027 and 5280863, respectively). Protein-ligand binding modeling was set up in consideration of protein crystal structure, inhibition constant, intramolecular energy, and minimal binding energy using Autodock Tool version 4.2.6 (The Scripps Research Institute, La Jolla, CA, USA). The implemented complex was analyzed with Ligplot ver. 4.5.3 provided by EMBLEBI and PyMOL ver. 1.8.4.2 provided by Schrödinger. Using PyMOL, 3D docking models of human $5-\mathrm{HT}_{3 \mathrm{~A}}$ receptor wild-type and mutant and ligand complexes were composed and distances between atoms of wild-type and mutant-type $5-\mathrm{HT}_{3 \mathrm{~A}}$ were measured.

\subsection{Statistical Analysis}

All presented experiments were performed at least three times for scientific verification. Data are presented as mean \pm S.E.M (standard error of the mean). Induced-inward current data were analyzed with SigmaPlot 10.0 software (Systat Software, Inc., San Jose, CA, USA). To prepare a sigmoid prediction curve for induced peak data, Hill equation reflecting the binding to ligand and macromolecule was obtained with an OriginPro 9.0 software (Origin, $\mathrm{MA}$, USA). The formula used was $\mathrm{y}=\mathrm{V}_{\min }+\left(\mathrm{V}_{\max }-\mathrm{V}_{\min }\right) \times[\mathrm{x}]^{\mathrm{n}} /\left(\left[\mathrm{IC}_{50}\right]^{\mathrm{n}}+[\mathrm{x}]^{\mathrm{n}}\right)$, where $\mathrm{V}_{\min }$ was the minimum current, $\mathrm{V}_{\max }$ was the maximum current, $\mathrm{IC}_{50}$ was the maximum half inhibitory effect percentage of inhibitory activation by KAE, $[x]$ was the concentration of serotonin or KAE, and $\mathrm{n}$ was the interaction-coefficient. Statistical significance was considered when $p$-value was less than or equal to $0.05(p \leq 0.05)$. 


\begin{abstract}
Author Contributions: Conceptualization, J.H.L. and T.-H.K.; methodology, H.-S.S.; software, J.L.; validation, C.K., H.-S.S. and J.-H.P.; formal analysis, J.H.L.; investigation, S.L.; resources, S.E.; data curation, S.L.; writing—original draft preparation, H.-S.S. and S.E.; writing—review and editing, S.E.; visualization, H.-S.S. and J.L.; supervision, J.H.L.; project administration, T.-H.K.; funding acquisition, J.H.L. All authors have read and agreed to the published version of the manuscript.
\end{abstract}

Funding: This work was supported by grants (2021R1A4A1031220) of the National Research Foundation (NRF) funded by Korea government.

Institutional Review Board Statement: The study was approved by the Institutional Review Board of Chonnam National University (CNU IACUC-YB-201607).

Informed Consent Statement: Not applicable.

Data Availability Statement: Data is contained within the article.

Conflicts of Interest: The authors declare no conflict of interest.

\title{
References
}

1. Fakhfouri, G.; Rahimian, R.; Dyhrfjeld-Johnsen, J.; Zirak, M.R.; Beaulieu, J.-M. 5-HT3 Receptor Antagonists in Neurologic and Neuropsychiatric Disorders: The Iceberg Still Lies beneath the Surface. Pharmacol. Rev. 2019, 71, 383-412. [CrossRef] [PubMed]

2. Buhot, M.-C.; Martin, S.; Segu, L. Role of serotonin in memory impairment. Ann. Med. 2000, 32, 210-221. [CrossRef] [PubMed]

3. Buhot, M.-C. Serotonin receptors in cognitive behaviors. Curr. Opin. Neurobiol. 1997, 7, 243-254. [CrossRef]

4. Thompson, A.J. Recent developments in 5-HT3 receptor pharmacology. Trends Pharmacol. Sci. 2013, 34, 100-109. [CrossRef]

5. Hannon, J.; Hoyer, D. Molecular biology of 5-HT receptors. Behav. Brain Res. 2008, 195, 198-213. [CrossRef]

6. Brady, C.A.; Stanford, I.M.; Ali, I.; Lin, L.; Williams, J.M.; Dubin, A.E.; Hope, A.G.; Barnes, N.M. Pharmacological comparison of human homomeric 5-HT3A receptors versus heteromeric 5-HT3A/3B receptors. Neuropharmacology 2001, 41, 282-284. [CrossRef]

7. Faerber, L.; Drechsler, S.; Ladenburger, S.; Gschaidmeier, H.; Fischer, W. The neuronal 5-HT3 receptor network after 20 years of research-Evolving concepts in management of pain and inflammation. Eur. J. Pharmacol. 2007, 560, 1-8. [CrossRef]

8. Yuan, S.; Filipek, S.; Vogel, H. A Gating Mechanism of the Serotonin 5-HT 3 Receptor. Structure 2016, 24, 816-825. [CrossRef]

9. Thompson, A.J.; Lummis, S.C.R. The 5-HT3receptor as a therapeutic target. Expert Opin. Ther. Targets 2007, 11, 527-540. [CrossRef] [PubMed]

10. Krzywkowski, K.; Davies, P.A.; Feinberg-Zadek, P.L.; Brauner-Osborne, H.; Jensen, A.A. High-frequency HTR3B variant associated with major depression dramatically augments the signaling of the human 5-HT3AB receptor. Proc. Natl. Acad. Sci. USA 2008, 105, 722-727. [CrossRef] [PubMed]

11. Corrie, J.; Baenziger, J.E. Gating of pentameric ligand-gated ion channels: Structural insights and ambiguities. Structure 2013, 21, $1271-1283$.

12. Lee, B.W.; Lee, J.H.; Lee, S.-T.; Lee, H.S.; Lee, W.S.; Jeong, T.-S.; Park, K.H. Antioxidant and cytotoxic activities of xanthones from Cudrania tricuspidata. Bioorganic Med. Chem. Lett. 2005, 15, 5548-5552. [CrossRef] [PubMed]

13. Sharma, K.; Kumar, V.; Kumar, S.; Sharma, R.; Mehta, C.M. Bauhinia variegata: A comprehensive review on bioactive compounds, health benefits and utilization. Adv. Tradit. Med. 2020, 21, 645-653. [CrossRef]

14. Imran, M.; Salehi, B.; Sharifi-Rad, J.; Gondal, T.A.; Saeed, F.; Imran, A.; Shahbaz, M.; Fokou, P.V.T.; Arshad, M.U.; Khan, H.; et al. Kaempferol: A Key Emphasis to Its Anticancer Potential. Molecules 2019, 24, 2277. [CrossRef] [PubMed]

15. Calderon-Montano, J.M.; Burgos-Moron, E.; Perez-Guerrero, C.; Lopez-Lazaro, M. A Review on the Dietary Flavonoid Kaempferol. Mini-Rev. Med. Chem. 2011, 11, 298-344. [CrossRef]

16. Schroeter, H.; Spencer, J.P.; Rice-Evans, C.; Williams, R.J. Flavonoids protect neurons from oxidized low-density-lipoproteininduced apoptosis involving c-Jun N-terminal kinase (JNK), c-Jun and caspase-3. Biochem. J. 2001, 358, 547-557. [CrossRef]

17. Żuk, M.; Kulma, A.; Dymińska, L.; Szołtysek, K.; Prescha, A.; Hanuza, J.; Szopa, J. Flavonoid engineering of flax potentiate its biotechnological application. BMC Biotechnol. 2011, 11, 10. [CrossRef]

18. Wang, L.; Tu, Y.-C.; Lian, T.-W.; Hung, J.-T.; Yen, J.-H.; Wu, M.-J. Distinctive Antioxidant and Antiinflammatory Effects of Flavonols. J. Agric. Food Chem. 2006, 54, 9798-9804. [CrossRef]

19. Li, S.; Pu, X.-P. Neuroprotective Effect of Kaempferol against a 1-Methyl-4-phenyl-1,2,3,6-tetrahydropyridine-Induced Mouse Model of Parkinson's Disease. Biol. Pharm. Bull. 2011, 34, 1291-1296. [CrossRef] [PubMed]

20. Sloley, B.D.; Urichuk, L.J.; Morley, P.; Durkin, J.; Shan, J.J.; Pang, P.K.T.; Coutts, R.T. Identification of Kaempferol as a Monoamine Oxidase Inhibitor and Potential Neuroprotectant in Extracts of Ginkgo Biloba Leaves. J. Pharm. Pharmacol. 2010, 52, 451-459. [CrossRef]

21. Jabbari, S.; Bananej, M.; Zarei, M.; Komaki, A.; Hajikhani, R. Possible Involvement of Serotonergic Mechanism(s) in the Antinociceptive Effects of kaempferol. Avicenna J. Neuro. Psycho. Physiol. 2020, 8, 64-70. [CrossRef]

22. Lochner, M.; Thompson, A.J. The muscarinic antagonists scopolamine and atropine are competitive antagonists at 5-HT 3 receptors. Neuropharmacology 2016, 108, 220-228. [CrossRef] [PubMed] 
23. Thompson, A.; Lummis, S. Discriminating between 5-HT3A and 5-HT3AB receptors. Br. J. Pharmacol. 2013, 169, 736-747. [CrossRef] [PubMed]

24. Kannan, K.; Jain, S.K. Oxidative stress and apoptosis. Pathophysiology 2000, 7, 153-163. [CrossRef]

25. Poh Loh, K.; Hong Huang, S.; De Silva, R.; Tan, H.; Benny, K.; Zhun Zhu, Y. Oxidative Stress: Apoptosis in Neuronal Injury. Curr. Alzheimer Res. 2006, 3, 327-337. [CrossRef]

26. Wang, J.; Mao, J.; Wang, R.; Li, S.; Wu, B.; Yuan, Y. Kaempferol Protects Against Cerebral Ischemia Reperfusion Injury Through Intervening Oxidative and Inflammatory Stress Induced Apoptosis. Front. Pharmacol. 2020, 11, 424. [CrossRef] [PubMed]

27. Holford, N.; Sheiner, L.B. Understanding the Dose-Effect Relationship. Clin. Pharmacokinet. 1981, 6, 429-453. [CrossRef] [PubMed]

28. Currie, G.M. Pharmacology, Part 1: Introduction to Pharmacology and Pharmacodynamics. J. Nucl. Med. Technol. 2018, 46, 81-86. [CrossRef]

29. Fiebich, B.L.; Akundi, R.S.; Seidel, M.; Geyer, V.; Haus, U.; Müller, W.; Stratz, T.; Candelario-Jalil, E. Expression of 5-HT3A receptors in cells of the immune system. Scand. J. Rheumatol. Suppl. 2004, 119, 9-11. [CrossRef]

30. Kesters, D.; Thompson, A.J.; Brams, M.; van Elk, R.; Spurny, R.; Geitmann, M.; Villalgordo, J.M.; Guskov, A.; Danielson, H.; Lummis, S.C.R.; et al. Structural basis of ligand recognition in 5-HT 3 receptors. EMBO Rep. 2013, 14, 49-56. [CrossRef]

31. Bhattacharya, A.; Dang, H.; Zhu, Q.-M.; Schnegelsberg, B.; Rozengurt, N.; Cain, G.; Prantil, R.; Vorp, D.A.; Guy, N.; Julius, D.; et al. Uropathic Observations in Mice Expressing a Constitutively Active Point Mutation in the 5-HT3A Receptor Subunit. J. Neurosci. 2004, 24, 5537-5548. [CrossRef] [PubMed]

32. Eom, S.; Lee, J.; Baek, Y.-B.; Yeom, H.D.; Lee, S.; Kim, C.; Park, Y.; Park, S.-I.; Lee, C.-M.; Lee, J.H. Identification and molecular study on the interaction of Schisandrin C with human 5-HT3A receptor. Eur. J. Pharmacol. 2021, 906, 174220. [CrossRef] [PubMed]

33. Miquel, M.C.; Emerit, M.B.; Nosjean, A.; Simon, A.; Rumajogee, P.; Brisorgueil, M.J.; Doucet, E.; Hamon, M.; Verge, D. Differential subcellular localization of the 5-HT3-As receptor subunit in the rat central nervous system. Eur. J. Neurosci. 2002, 15, 449-457. [CrossRef] [PubMed]

34. Maura, G.; Andrioli, G.C.; Cavazzani, P.; Raiteri, M. 5-Hydroxytryptamine3Receptors Sited on Cholinergic Axon Terminals of Human Cerebral Cortex Mediate Inhibition of Acetylcholine Release. J. Neurochem. 1992, 58, 2334-2337. [CrossRef] [PubMed]

35. Duffy, N.H.; Lester, H.A.; Dougherty, D.A. Ondansetron and Granisetron Binding Orientation in the 5-HT3 Receptor Determined by Unnatural Amino Acid Mutagenesis. ACS Chem. Biol. 2012, 7, 1738-1745. [CrossRef]

36. Papke, R.; Papke, J.K.P.; Rose, G. Activity of $\alpha 7$-selective agonists at nicotinic and serotonin 5 HT3 receptors expressed in Xenopus oocytes. Bioorganic Med. Chem. Lett. 2004, 14, 1849-1853. [CrossRef]

37. Rammes, G.; Eisensamer, B.; Ferrari, U.; Shapa, M.; Gimpl, G.; Gilling, K.; Parsons, C.; Riering, K.; Hapfelmeier, G.; Bondy, B.; et al. Antipsychotic drugs antagonize human serotonin type 3 receptor currents in a noncompetitive manner. Mol. Psychiatry 2004, 9 846-858. [CrossRef]

38. Fakhfouri, G.; Rahimian, R.; Ghia, J.-E.; Khan, W.I.; Dehpour, A.R. Impact of 5-HT3 receptor antagonists on peripheral and central diseases. Drug Discov. Today 2012, 17, 741-747. [CrossRef]

39. Dremencov, E.; Weizmann, Y.; Kinor, N.; Gispan-Herman, I.; Yadid, G. Modulation of Dopamine Transmission by 5HT2C and 5HT3 Receptors: A Role in the Antidepressant Response. Curr. Drug Targets 2006, 7, 165-175. [CrossRef]

40. Serhan, C.N.; Chiang, N.; Van Dyke, T.E. Resolving inflammation: Dual anti-inflammatory and pro-resolution lipid mediators. Nat. Rev. Immunol. 2008, 8, 349-361. [CrossRef] [PubMed]

41. Niesler, B.; Frank, B.; Kapeller, J.; Rappold, G.A. Cloning, physical mapping and expression analysis of the human 5-HT3 serotonin receptor-like genes HTR3C, HTR3D and HTR3E. Gene 2003, 310, 101-111. [CrossRef] 